\title{
First report of Syrphophagus aphidivorus (Hymenoptera: Encyrtidae) on Aphidius ervi in alfalfa crops in State of São Paulo, Brazil
}

\author{
L. G. R. Iemma ${ }^{a}$, M. T. Tavares ${ }^{b}$ and C. R. Sousa-Silva ${ }^{a}$ \\ aPrograma de Pós-graduação em Ecologia e Recursos Naturais, Laboratório de Entomologia Aplicada - LEA, \\ Departamento de Ecologia e Biologia Evolutiva, Universidade Federal de São Carlos - UFSCAR, Rodovia Washington \\ Luis, Km 235, CP 676, CEP 13565-905, São Carlos, SP, Brazil \\ bLaboratório de Biodiversidade de Insetos - LABI, Departamento de Ciências Biológicas, Universidade Federal do \\ Espírito Santo - UFES, Avenida Marechal Campos, 1468, CEP 29040-090, Vitória, ES, Brazil \\ *e-mail: luis_iemma@yahoo.com.br
}

Received: December 21, 2015 - Accepted: April 13, 2016 - Distributed: May 31, 2017

(With 3 Figures)

Encyrtidae is a large family of parasitic wasps with about 3000 described species in about 450 genera. Most species of Encyrtidae are primary endoparasitoids of other arthropods or secondary parasitoids via other hymenopterous parasitoids (Hanson and Gauld, 1995).

Among the koinobiont Encyrtidae, the Syrphophagus aphidivorus (Mayr 1876) host selection behavior is atypical. The hyperparasitoid females have two oviposition strategies: they can lay eggs in living parasitized aphids as in mummified aphids. Both strategies aim to attack the larvae of primary parasitoids (Kanuck and Sullivan, 1992).

Specimens of $S$. aphidivorus were obtained from the primary parasitoid Aphidius ervi Haliday, 1834 (Hymenoptera: Braconidae) on Acyrthosiphon pisum Harris, 1776 (Hemiptera: Aphididae) host collected in alfalfa (Medicago sativa) in "Embrapa Pecuária Sudeste", located in São Carlos - SP and individually separated into Eppendorf microtubes $(1.5 \mathrm{ml})$. In the laboratory, the parasitized hosts were allocated in a room with temperature around $25^{\circ} \mathrm{C}$. After the emergence of adults, the specimens were kept in the freezer until their identification.

The aphids were identified by the last author and the parasitoids and hyperparasitoids were identified by the first author, using a key of identification provided by Hanson and Gauld (1995) for parasitoids and Fergusson (1980). The specimens were studied under a Leica M125 stereomicroscope with a 16x ocular, Images were captured using an automated Z16 Leica system and a DFG495 Leica Digital camera.

During the sampling period, nine specimens of Syrphophagus aphidivorus were reared from the primary parasitoids

S. aphidivorus have a clava apically with at least a short oblique truncation (Figure 1), scutellum more or less evenly sculptured, never with a sculpture at base contrasting so strongly with that at apex (Figure 2). Median region of propodeum smooth and venation of forewing usually dark brown (Figure 2). The antennae have a scape at least three and a half times as long as broad (Figure 3 ).
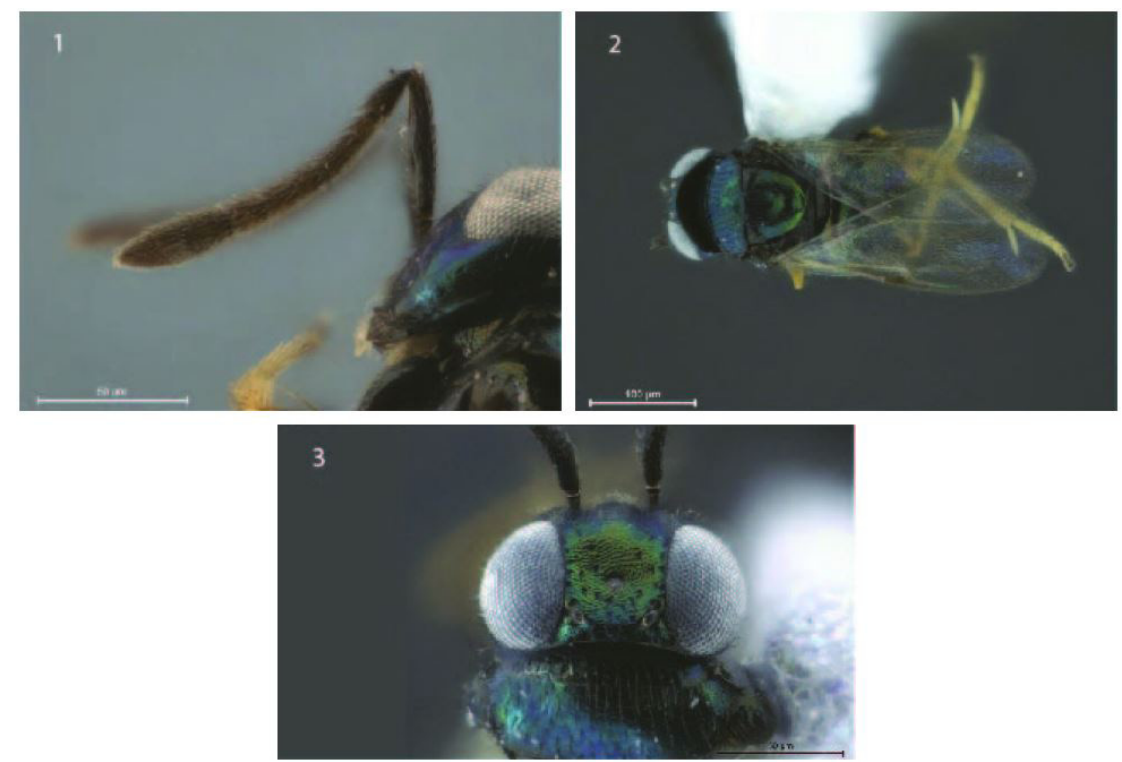

Figures 1-3. Syrphophagus aphidivorus. (Mayr, 1876) (Hymenoptera, Encyrtidae) (1- Antennae; 2- Body, dorsal view; 3-Head and Antennae, dorsal view). 
This species has documented occurrence to the State of Paraná wheat crops (Zanini, 2004) and to the State of São Paulo in oatmeal crops (Ronquim et al., 2004), this is the first report of this species to the State of São Paulo in alfalfa crop.

\section{Acknowledgements}

To the Coordenação de Aperfeiçoamento de Pessoal de Nível Superior (CAPES) for the financial support.

\section{References}

FERGUSSON, N.M.D., 1980. A revision of the british species of Dendrocerus Ratzeburg (Hymenoptera, Ceraphronoidea) with a review of their biology as aphid hyperparasites. Bulletin of the British Museum (Natural History). Historical Series, vol. 41, pp. 255-314. http://dx.doi.org/10.5962/bhl.part.28549.
HANSON, P. and GAULD, I.D., 1995. The Hymenoptera of Costa Rica. London: University Press. 893 p.

KANUCK, M.J.D. and SULLIVAN, J., 1992. Ovipositional behavior and larval development of Aphidencyrtus aphidivorus (Hymenoptera: Encyrtidae), an aphid hyperparasitoid. Journal of the New York Entomological Society, vol. 100, pp. 527-532.

RONQUIM, J.C., PACHECO, J.M. and RONQUIM, C.C., 2004. Occurrence and parasitism of aphids (Hemiptera: Aphididae) on cultivars of irrigated oat (Avena spp.) in São Carlos, Brazil. Brazilian Archives of Biology and Technology, vol. 47, no. 2, pp. 163-169. http://dx.doi.org/10.1590/S151689132004000200001

ZANINI, A., 2004. Controle biológico do pulgão de trigo Sitobion avenae (Fabricius 1775) pelo parasitoide Aphidius colemani Viereck, 1912 em Medianeira, PR, Brasil. Cascavel: Universidade Estadual do Oeste do Paraná, 77 p. Dissertação de Mestrado em Agronomia. 